Bangladesh J. Bot. 40(2): 163-169, 2011 (December)

\title{
NEW RECORD OF PLANKTONIC DIATOMS FROM THE SUNDARBAN MANGROVE FORESTS, BANGLADESH
}

\author{
Abdul Aziz* and Mashrura Rahman \\ Department of Botany, University of Dhaka, Dhaka-1000, Bangladesh
}

Key words: Phytoplankton, Diatoms, Mangrove, Estuarine algae, Centrales, Pennales

\begin{abstract}
Botanical expedition to the Sundarban Mangrove Forests in the Bangladesh part revealed the presence of 14 diatom taxa not recorded so far from Bangladesh territory. The taxa are Amphiprora alata Kütz., Chaetoceros pendulus Karsten, Chaetoceros socialis Lauder, Cyclotella comta (Ehr.) Kütz. Thalassionema nitzschioides (Grun.) Meresch, Thalassiosira rotula Meunier, Thalassiosira weisflogii Grun., Lioloma delicatula (Cupp) Hasle, Navicula brekkaensis Petersen fa, Nitzschia inconspicua Grun. fa, Nitzschia romana Grun., Surirella fastuosa var. recedens (Schm.) Cl. Besides these, unidentified species of Chaetoceros sp. and an unidentified centric diatom have been recorded. These newly recorded taxa are described and illustrated.
\end{abstract}

\section{Introduction}

The estuaries of Sundarban Mangrove Forests (SMF) is important for fisheries sector. It is contributing about $0.36 \mathrm{M}$ US\$/year in the revenue earnings of Bangladesh. This sector of fisheries is supported by phytoplankton, which enter into the food chain. But no information is available on the phytoplankton of the SMF in the Bangladesh part (Karim 1994). The only record of attached and terrestrial algae from SMF was by Islam (1973). Aziz (2005) recorded brackish water diatoms from Rupsha River near Khulna Launch Ghat situated about 100 km north of SMF. The present study was thus undertaken to record the diversity of phytoplankton within the SMF of Bangladesh. A total of 36 taxa were recorded (Aziz et al. 2011) of which 15 diatom taxa reported in this paper do not fit systematically with the diatoms of the Bay of Bengal (Aziz and Islam 1979, Islam and Aziz 1975, 1980), Karnaphuli River estuary (Islam and Aziz 1977) and coasts of Moheshkhali Island (Islam and Aziz 1979) and those reported in Ahmed et al. (2009).

\section{Materials and Methods}

A total of 65 phytoplankton samples from 8 locations were collected between 25 and 29 March, 2010 from four Ranges covering about 70\% of the Sundarban Mangrove Forests (Table 1). From each site, five samples were collected during high and or low tides by passing 22 litre water for each sample, through $40 \mu \mathrm{m}$ mesh plankton net. The final volume of the sample was $20 \mathrm{ml}$ and preserved in Lugol's solution.

Table 1. Collection sites, sample numbers, Ranges, latitude and longitude, etc. of the sites.

\begin{tabular}{|c|c|c|c|c|c|}
\hline $\begin{array}{l}\text { Date of } \\
\text { collections }\end{array}$ & Site nos. \& names & $\begin{array}{l}\text { Sampl } \\
\text { e nos. }\end{array}$ & $\begin{array}{l}\text { Time of } \\
\text { collections }\end{array}$ & Ranges & $\begin{array}{l}\text { Lat. \& long. } \\
\text { of sites }\end{array}$ \\
\hline 25.03 .2010 & 1. Passar R. & $1-5$ & low tide & Nalianala (Khulna) & $\begin{array}{l}21^{\circ} 27^{\prime} 03^{\prime \prime} \mathrm{N} \\
89^{\circ} 35^{\prime} 29^{\prime \prime} \mathrm{E}\end{array}$ \\
\hline 26.03.2010 & $\begin{array}{l}\text { 2. Sela R. near } \\
\text { Tambulbunia F.S. }\end{array}$ & $6-10$ & $\begin{array}{l}\text { high \& low } \\
\text { tides }\end{array}$ & Chandpai & $\begin{array}{l}22^{\circ} 15^{\prime} 43^{\prime \prime} \mathrm{N} \\
89^{\circ} 43^{\prime} 59^{\prime \prime} \mathrm{E}\end{array}$ \\
\hline 26.03 .2010 & 3. Harmal R., Tek & $11-15$ & low tide & $\begin{array}{l}\text { Chandpai-Sarankhola } \\
\text { border }\end{array}$ & $\begin{array}{l}22^{\circ} 01^{\prime} 36^{\prime \prime} \mathrm{N} \\
89^{\circ} 43^{\prime} 59^{\prime \prime} \mathrm{E}\end{array}$ \\
\hline 27.03.2010 & 4. Betmara R. Kotka F.S. & $16-25$ & $\begin{array}{l}\text { high \& low } \\
\text { tides }\end{array}$ & Sarankhola & $\begin{array}{l}22^{\circ} 15^{\prime} 43^{\prime \prime} \mathrm{N} \\
89^{\circ} 41^{\prime} 50^{\prime \prime} \mathrm{E} \\
\end{array}$ \\
\hline
\end{tabular}

*E-mail: <dr.aziz.botany@gmail.com>. 


\begin{tabular}{|c|c|c|c|c|c|}
\hline 28.03.2010 & $\begin{array}{l}\text { 5. Conjoint of Hansharaj } \\
\text { \& Mardat R. }\end{array}$ & $26-30$ & $\begin{array}{l}\text { high \& low } \\
\text { tides }\end{array}$ & Nalianala & $\begin{array}{l}22^{\circ} 04^{\prime} 31^{\prime \prime} \mathrm{N} \\
89^{\circ} 28^{\prime} 07^{\prime \prime} \mathrm{E}\end{array}$ \\
\hline 28.03.2010 & $\begin{array}{l}\text { 6. Near conjoint of Bal \& } \\
\text { Arpangasia R. }\end{array}$ & $36-45$ & $\begin{array}{l}\text { high \& low } \\
\text { tides }\end{array}$ & $\begin{array}{l}\text { Nalianala- } \\
\text { Burigoalini border }\end{array}$ & $\begin{array}{l}21^{\circ} 59^{\prime} 07^{\prime \prime} \mathrm{N} \\
89^{\circ} 20^{\prime} 48^{\prime \prime} \mathrm{E}\end{array}$ \\
\hline 29.03.2010 & $\begin{array}{l}\text { 7. Bishandirkhal, east of } \\
\text { Shipsa R. }\end{array}$ & $46-50$ & low tide & Nalianala & $\begin{array}{l}22^{\circ} 05^{\prime} 49^{\prime \prime} \mathrm{N} \\
88^{\circ} 32^{\prime} 22^{\prime \prime} \mathrm{E}\end{array}$ \\
\hline 29.03.2010 & $\begin{array}{l}\text { 8. Shipsa R. near } \\
\text { Chailabogi F.S. }\end{array}$ & $51-55$ & low tide & Nalianala & $\begin{array}{l}22^{\circ} 11^{\prime} 27^{\prime \prime} \mathrm{N} \\
89^{\circ} 29^{\prime} 01^{\prime \prime} \mathrm{E}\end{array}$ \\
\hline 29.03.2010 & $\begin{array}{l}\text { 9. Kalabogi R. near Aila } \\
\text { heat area }\end{array}$ & $56-60$ & low tide & Nalianala & $\begin{array}{l}22^{\circ} 20^{\prime} 51^{\prime \prime} \mathrm{N} \\
88^{\circ} 29^{\prime} 07^{\prime \prime} \mathrm{E}\end{array}$ \\
\hline
\end{tabular}

Identification of phytoplankton taxa were made following Ahmed et al. (2009), Cupp (1943), Germain (1981) and Subrahmanyan (1946).

\section{Results and Discussion}

A total of 14 phytoplankton taxa namely, Amphiprora alata Kütz., Chaetoceros pendulus Karsten, Chaetoceros socialis Lauder, Chaetoceros sp., Cyclotella comta (Ehr.) Kütz. Thalassionema nitzschioides (Grun.) Meresch, Thalassiosira rotula Meunier, Thalassiosira weisflogii Grun., Lioloma delicatula (Cupp) Hasle, Navicula brekkaensis Petersen fa., Nitzschia inconspicua Grun. fa, Nitzschia romana Grun., Surirella fastuosa var. recedens (Schm.) Cl. and an unidentified centric diatom, were found for the first time in the SMF of Bangladesh territory. These taxa were not recorded from SMF of Indian part (Chaudhuri and Choudhury 1994). An illustrated account and taxonomy of these newly recorded taxa have been provided and discussed in this paper.

\section{Class: Bacillariophyceae Order: Centrales Family: Skeletonemaceae Genus: Thalassiosira $\mathrm{Cl}$}

\section{Thalassiosira rotula Meunier}

(Cupp 1943, 49, fig. 12 )

Cells disc-shaped, valves flat, $25.4 \mu \mathrm{m}$ in diameter. Valve processes a central spine. Areolae very fine, indistinct.

The taxon was recorded from Betmara R., during high and low tides near Katka, Sarankhola Range.

\section{Thalassiosira weisflogii Grun.}

(Germain 1981, 42, pl.10, fig.14-16)

Valves circular, flat, $20.32 \mu \mathrm{m}$ in diameter, areolae coarse in the margin, much smaller towards center, irregular rows. Marginal and central zones not clearly distinguishable.

Notes: The material may be confused with Cyclotella spp.

The taxon was recorded from Harmal R. during low tide, Chandpai-Sarankhola Range border; confluence of Mordat and Hangsharaj R. during high and low tide and Bal R. during low tide, Burigoalini-Nalianala Range border.

\section{Cyclotella comta (Ehr.) Kütz.}

\section{Genus: Cyclotella (Kütz.) Breb.}

(Germain 1981, 32, pl. 8, figs 1-7)

Valve disc-shaped, margins with radiate striae in the inter-marginal zone, apparently cellular, giving appearance of spines, central portion of valve distinct, panctate; valves $47.8 \mu \mathrm{m}$ in diameter. 
The taxon was recorded from Harmal R. during low tide, Chandpai-Sarankhola Range border; Betmara R., during high tide near Katka, Sarankhola Range; confluence of Mordat and Hangsharaj R. during high and low tide and Bal R. during low tide, Burigoalini-Nalianala Range border.

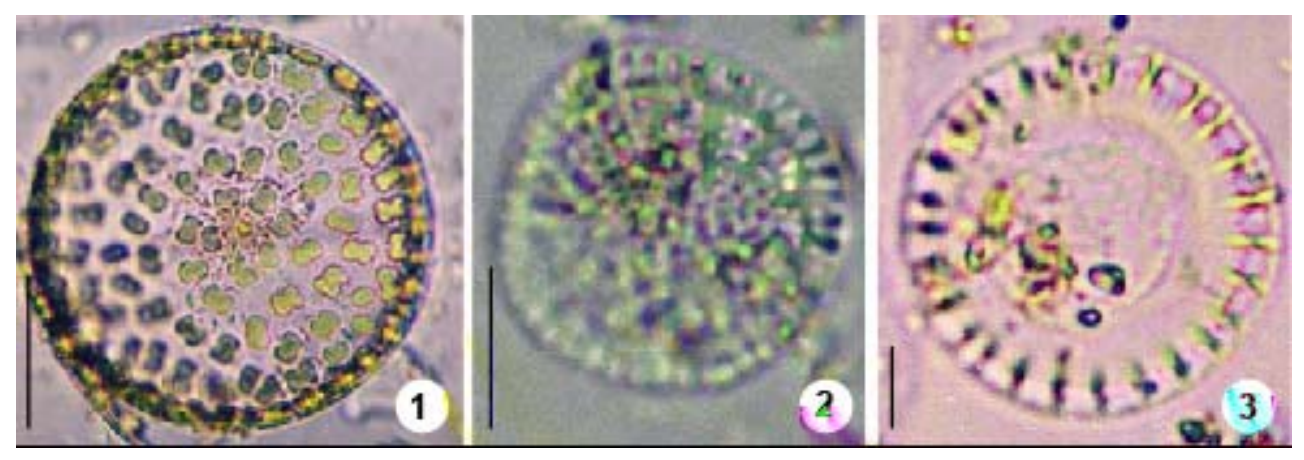

Figs 1 - 3. 1. Thalassiosira rotula Meunier, valve view. 2. T. weisflogii Grun., valve view. 3. Cyclotella comta (Ehr.) Kütz. Bars $=20 \mu \mathrm{m}$.

\section{Family: Chaetoceraceae Genus: Chaetoceros Ehr.}

\section{Chaetoceros pendulus Karsten}

(Cupp 1943, 114, fig. 69)

Cells solitary, 9-18 $\mu \mathrm{m}$ width; valves unlike, upper one with deep depression in the center, lower with projecting corners. Chaete smooth, very long, sloping diagonally outwards from upper valve then running in large sweeping curve. Chaete of lower valve strongly bent backwardly, proceed almost parallel. Chromatophores many, small, short-cylindrical, also distributed far out in the chaete.

The taxon was recorded from Betmara R., during high tide near Katka, Sarankhola Range; confluence of Mordat and Hangsharaj R. during high and low tide.

\section{Chaetoceros socialis Lauder}

(Fig. 5)

(Subrahmanyan 1946, 143, figs 251)

Frustules 10-12 $\mu \mathrm{m}$ width, chaete 4, delicate, curved. Two from corner of each valve, 8-10 elipsoidal chromatophores. Colony 3-4 celled with chaete being arranged in a more or less same direction.

The taxon was recorded from Passar R. in the outskirt of SMF near Chandpai Range.

\section{Chaetoceros sp.}

(Fig. 6)

Valves almost circular, producing 2 straight chaete in opposite directions. Chaete of one valve disposed at right angle to chaete of other valve. Chaete with several short, rod-like plastids.

The taxon was recorded from Sela R. during high tide, Chandpai Range; confluence of Mordat and Hangsharaj R. during high tide, Nalianala Range.

\section{Unidentified centric diatom}

(Figs 7a-b)

Cells disc-shaped, valves convex, depressed at center, covering about 1/3 surface. Plastids discoid, 2.54-3.30 $\mu \mathrm{m}$ in diameter, scattered. Valves $116.84 \mu \mathrm{m}$ in diameter. 

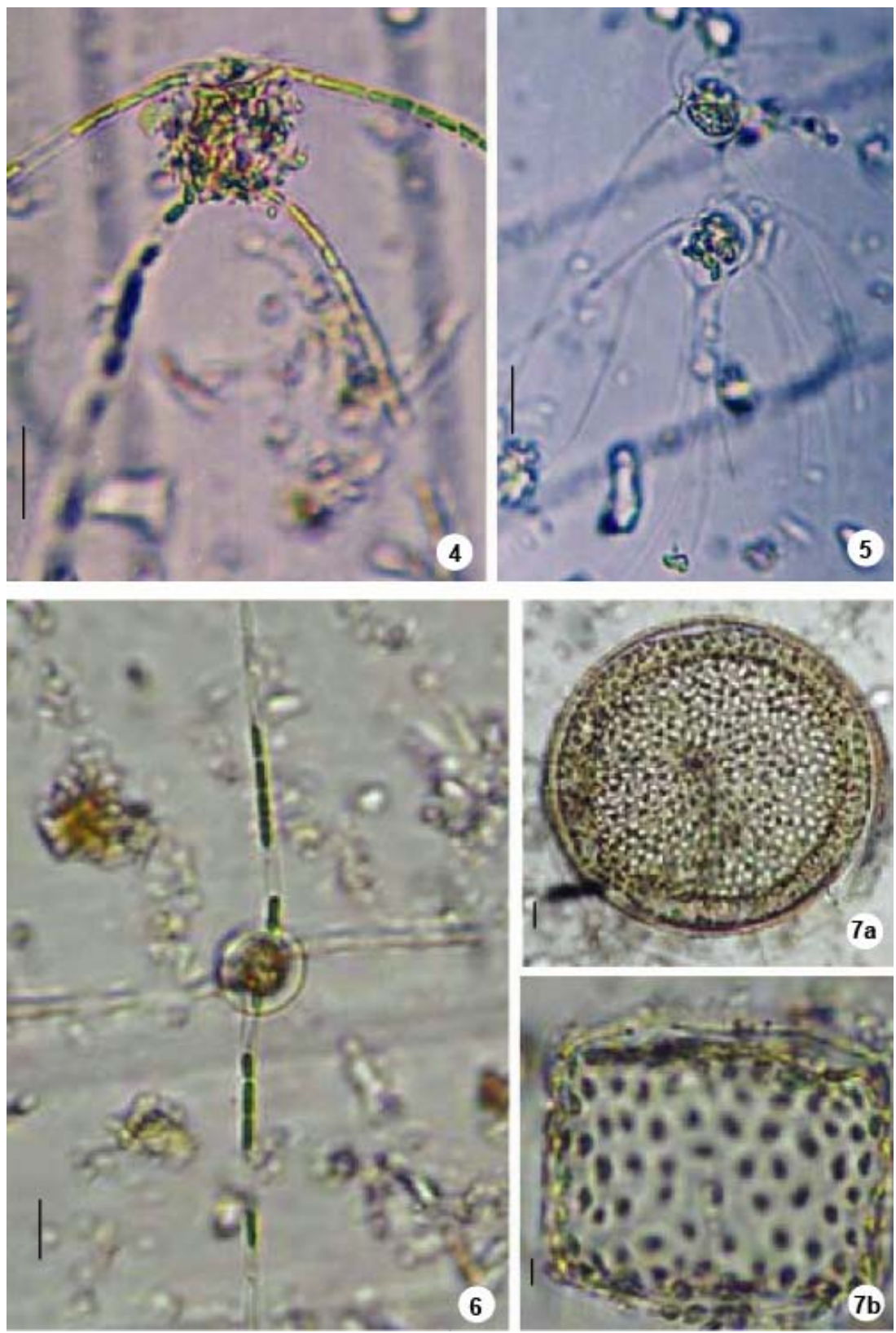

Figs 4 - 7. 4. Chaetoceros pendulus Karsten a solitary cell. 5. C. socialis Lauder, a colony of about 5 cells. 6. Chaetoceros sp., valve view of a frustule. 7a-b. Unidentified centric diatom, valve (a) and girdle (b) views. Bars: $10 \mu \mathrm{m}$, except 7a-b $=20 \mu \mathrm{m}$.

Notes: The valve surface seen in girdle view resembled strongly with Lauderia or Thalassiosira but bristles or spines absent.

The taxon was recorded from confluence of Mordat R. and Hangsharaj R. during high tide, Nalianala Range. 


\section{Order: Pennales Family: Fragilariaceae Genus: Thalassionema Grun.}

\section{Thalassionema nitzschioides (Grun.) Meresch}

(Subrahmanyan 1946, 167, figs 344-346; Cupp 1943, 182, fig.133)

(Figs 8a-b)

Cells united to each other by small gelatinous cushion; Girdle view narrow linear in median region with gradual narrowing up to both ends, valves narrow linear with parallel sides, blunt rounded ends, costae present. Frustules 38-40 $\mu \mathrm{m}$ long, 4-5 $\mu \mathrm{m}$ diameter.

The taxon was recorded from Sela R. during high tide, Chandpai Range; confluence of Mordat and Hangsharaj R. during high tide, Nalianala Range; Harmal R. during low tide, Chandpai-Sarankhola Range border; Betmara R., during low tide near Katka, Sarankhola Range.

\section{Genus: Lioloma Hasle}

\section{Lioloma delicatula (Cupp) Hasle}

Synonym: Thalassiothrix delicatula Cupp 1943, 188, fig. 181

(Figs 9a-b)

(Algaebase.org, 26 April, 2002)

Cells 1120-1920 $\mu \mathrm{m}$ long, slightly bent. One end bluntly pointed, widest point $1-2 \mu \mathrm{m}$, nearly same width until about one-third the length of cell from head end, then become slightly narrower, $1.5-2 \mu \mathrm{m}$ in diameter. Striae $20-24$ in $10 \mu \mathrm{m}$.

The taxon was recorded from Sela R. during high and low tides, Chandpai Range; confluence of Mordat and Hangsharaj R. during high and low tides, Nalianala Range; Bal R. during low tide, Burigoalini-Nalianala Range border; Brisindri Khal, during low tide, Nalianala Range.

\section{Family: Naviculaceae Genus: Navicula Bory}

\section{Navicula brekkaensis Petersen fa}

(Germain 1981, 224, pl. 84, figs 11-15)

Valves lanceolate to elongated almost parallel margin in mid region, tip roundish. Frustules 50-70 $\mu \mathrm{m}$ long, 7-8 $\mu \mathrm{m}$ broad. Straie 10 to 12 in $10 \mu \mathrm{m}$, chromatophores two, laminate.

Notes: The description and the frustule structure slightly varied from that of Germain (1981, 224, pl. 84, Figs13-15) and thus the present materials is identified as a forma of this species has been considered.

The taxon was recorded from all locations except ; Brisindri Khal.

11. Amphiprora alata Kütz.

(Germain 1981, 134, pl. 50, fig.3-4)

(Figs 12a-b)

Cells strongly constricted, $60.96 \mu \mathrm{m}$ long, $17.78 \mu \mathrm{m}$ broad towards end in girdle. Keel with hyline margin, 13-14 in $10 \mu \mathrm{m}$. Striae curved, divergent from central nodule, 12-14 in $10 \mu \mathrm{m}$.

The taxon was recorded from confluence of Mordat and Hangsharaj R. during low tide, Nalianala Range.

\section{Family: Nitzschiaceae Genus: Nitzschia Hassall}

12. Nitzschia inconspicua Grun. fa

(Germain 1981, 356, pl. 135, fig. 7)

(Fig. 10)

Frustules nearly ovate, valves $33.02 \mu \mathrm{m}$ long, $19.68 \mu \mathrm{m}$ broad. Striae transverse in median region, gradually convergent towards ends, 8-9 in $10 \mu \mathrm{m}$.

Notes: The present material is ovate, longer and with less striae in $10 \mu \mathrm{m}$ then that described by Germain (1981, 356, pl. 134, figs 23-26).

The taxon was recorded from Bal R. during low tide, Burigoalini-Nalianala Range border. 

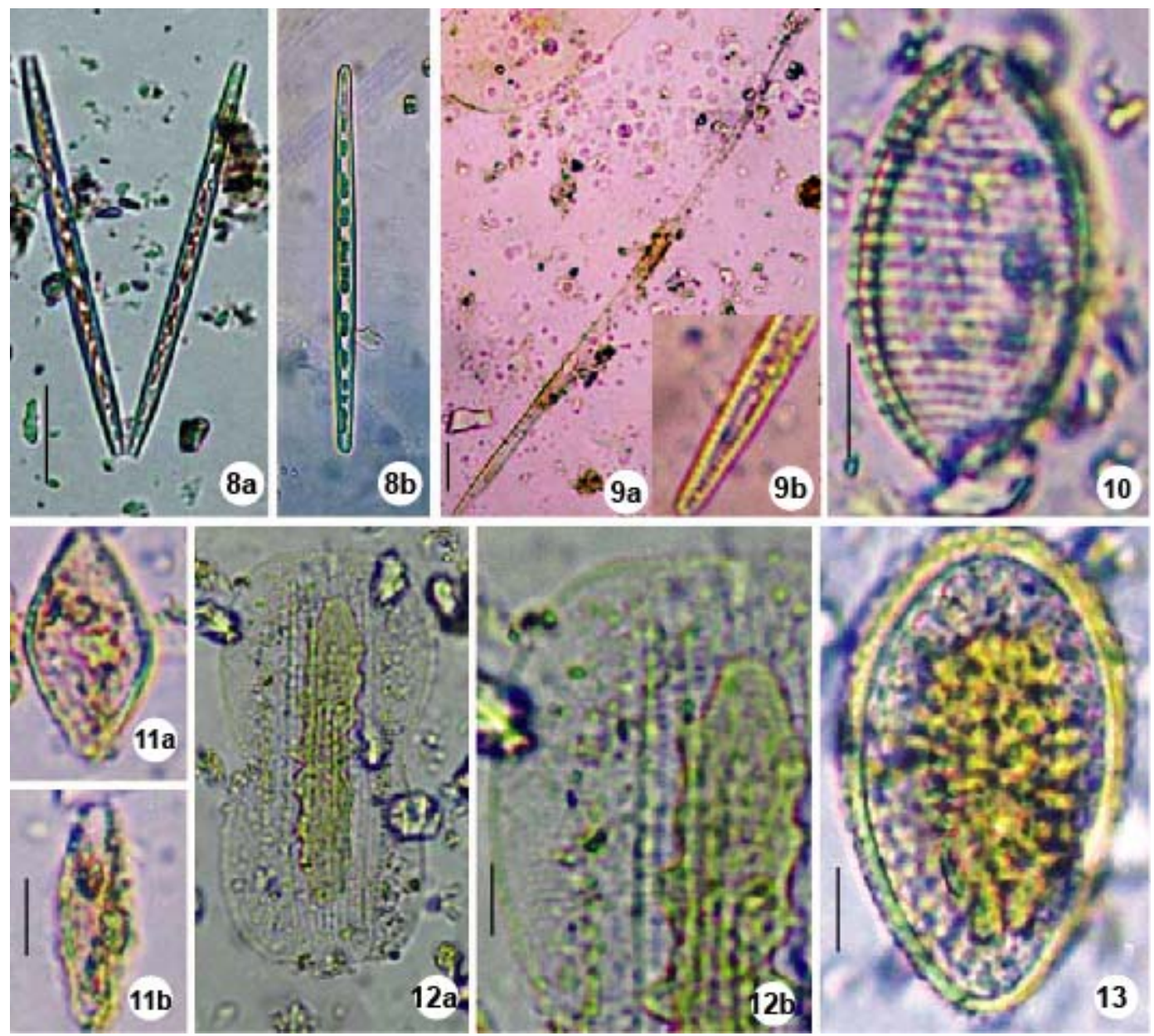

Figs 8 - 13. 8a-b. Thalassionema nitzschioides (Grun.) Meresch, two celled colony (a) and a frustule in valve view (b). 9a-b. Lioloma delicatula (Cupp) Hasle, a whole frustule (a) with basal part enlarged showing striae (b, inset). 10. Nitzschia inconspicua Grun. fa, valve view. 11a-b. N. romana Grun. (a. valve view, b. girdle view). 12a-b. Amphiprora alata Kütz. a whole cell (a), a portion enlarged showing striae and punctae (b). 13. Surirella fastuosa var. recedens (Schm.) Cl., valve view. Bars $=10 \mu \mathrm{m}$, except 9a Bar $=100 \mu \mathrm{m}$.

\section{Nitzschia romana Grun.}

(Figs 11a-b)

(Germain 1981, 356, pl.135, fig.7)

Frustules rhomboid, valves 25-27 $\mu \mathrm{m}$ long, $12-14 \mu \mathrm{m}$ broad, $14-15$ striae in $10 \mu \mathrm{m}$. Girdle view slightly sigmoid with rounded apex, 5.7-6.2 $\mu \mathrm{m}$ broad.

The taxon was recorded from Bal R. during low tide, Burigoalini-Nalianala Range border. 


\section{Family: Surirellaceae Genus: Surirella Turpin}

\section{Surirella fastuosa var. recendens (Schm.) Cl.}

(Cupp 1943, 208, fig.160)

(Fig. 13)

Frustules wedge-shaped, rounded at angles. Valves ovate. Costae or ribs about 3-4 in $10 \mu \mathrm{m}$, robust, dilated at margin. Central space lenceolate, narrower than type. Valve $55 \mu \mathrm{m}$ long, $38 \mu \mathrm{m}$ width.

The taxon was recorded from Sela R. during high and low tides and Chandpai Range and Betmara R., during low tide near Katka, Sarankhola Range.

\section{Acknowledgements}

Authors gratefully acknowledge the Honourable Vice Chancellor, University of Dhaka and the Chairman of the Department of Botany for supporting the Botanical Expedition to the Sundarban Mangrove Forests from 25 to 29 March, 2010.

\section{References}

Ahmed ZU, M Khondker, ZNT Begum, MA Hassan, SMH Kabir, M Ahmad, ATA Ahmed, AKA Rahman and EU Haque (Eds) 2009. Encyclopedia of Flora and Fauna of Bangladesh, Vol. 4. Algae: CharophytaRhodophyta. Asiat. Soc. Bangladesh, Dhaka. 543 pp.

Algaebase.org, 26 April, 2002

Aziz A 2005. Brackish water algae from Bangladesh. I. Biddulphia spp. Bangladesh J. Bot. 34(2): 109-114.

Aziz A, M Rahman and A Ahmad 2011. Distribution and abundance of phytoplankton in different locations of the Sundarban Mangrove Forests, Bangladesh. J. Bangladesh Acad. Sci. (submitted)

Aziz A and AKMN Islam 1979. Marine dinoflagellates from the Bay of Bangal, Bangladesh. J. Bangladesh Acad. Sci. 3(1-2): 41-49.

Chaudhuri AB and A Choudhury (Eds) 1994. Mangroves of the Sundarbans. Volume one: India. IUCN, Bangkok.

Cupp E.E. 1943. Marine plankton diatoms of the west coast of North America. Bull. Scripps Institute of Oceanography. Univ. of California press, Los Angeles.

Germain H 1981. Flore des diatom e'es eaux douces et saumatres. Societe nouvelle des editions Boubee, Paris. $444 \mathrm{pp}$.

Karim A 1994. Vegetation. In: Mangroves of the Sundarbans. Volume two: Bangladesh. Hussain Z and G Acharya (Eds), pp. 43-74. IUCN, Bangkok.

Islam AKMN 1973. The algal flora of Sundarbans Mangrove Forest Bangladesh. Bangladesh J. Bot. 2(2): 1136.

Islam AKMN and A Aziz. 1975. Study of marine phytoplankton from the north-eastern Bay of Bengal, Bangladesh. Bangladesh J. Bot. 4(1-2): 1-32

Islam AKMN and A Aziz 1977. Studies on the phytoplankton of the Karnaphuli river estuary. Bangladesh J. Acad. Sci. 1(2): 141-154.

Islam AKMN and A Aziz 1979. Algal flora of Moheshkhali Island, Bangladesh. Dhaka Univ. Stud. B 27(2): 105-122.

Islam AKMN and A Aziz 1980. Marine diatoms from the Bay of Bengal, Bangladesh. Bangladesh J. Bot. 9(1): 29-35.

Subrahmanyan R 1946. A systematic account of the marine plankton diatoms of the Madras coast. Proc. Ind. Acad. Sci. B 24: 85-197.

(Manuscript received on 13 September, 2011; revised on 13 November, 2011) 